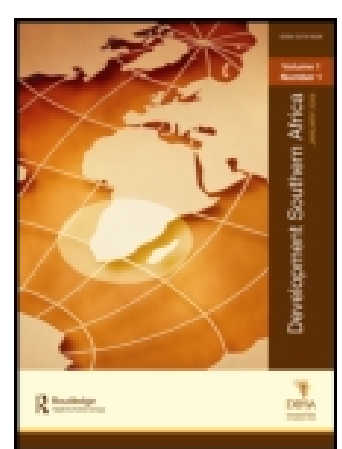

Development Southern Africa

\title{
Strangers in a strange land: citizenship and the immigration debate in Lesotho
}

\section{John K Akokpari}

To cite this article: John K Akokpari (2005) Strangers in a strange land: citizenship and the immigration debate in Lesotho, Development Southern Africa, 22:1, 87-102, DOI: 10.1080/03768350500044511

To link to this article: http://dx.doi.org/10.1080/03768350500044511

$$
\text { Published online: } 12 \text { Apr } 2011 .
$$

\section{Submit your article to this journal $\square$}

Щ Article views: 68 


\title{
Strangers in a strange land: citizenship and the immigration debate in Lesotho
}

\author{
John K Akokpari ${ }^{1}$
}

Lesotho, a small sovereign country located within the borders of the Republic of South Africa, displays a paradox as regards immigration. It lacks the attributes of a typical receiving country, but it has been attractive to immigrants, especially from those countries in sub-Saharan Africa which are not members of the Southern African Development Community (SADC). Lesotho's attraction to immigrants is explained largely by its ability to offer better remuneration for skilled workers than many non-SADC sub-Saharan African countries, and by its strategic location as an easy transit gate into South Africa, widely perceived as the 'Europe' of the continent. However, the influx of immigrants into Lesotho has generated a wave of anti-foreigner feelings among sections of the population and heightened the debate about the relevance of foreigners to national development. The paper reiterates the principal conventional arguments against immigration: that it compromises jobs, raises crime rates, intensifies the spread of diseases, undermines the homogeneity of the state and nation and exerts additional strain on the country's already overstretched resources. Demonstrating the limits of these arguments, the paper argues that for Lesotho, grappling with unemployment and manpower shortages, immigration is an asset rather than a liability because it creates jobs, brings in skills that are otherwise in short supply and raises the country's international profile and competitiveness.

\section{INTRODUCTION}

Lesotho, a small sovereign country located within the Republic of South Africa, displays unusual and paradoxical characteristics as regards immigration. Ordinarily, Lesotho would not seem likely to attract immigrants, given its weak industrial base and consequent inability to provide adequate formal and informal employment. Conventionally, the literature depicts Lesotho as a 'labour reserve': a source of labour for the mining industry in South Africa (Southall, 1984; Sachikonye, 1995; Matlosa, 1996). However, over the last few years Lesotho has become one of the largest receiving countries of immigrants within the Southern African Development Community (SADC), ${ }^{2}$ after South Africa and Botswana. Most of these immigrants come from outside the SADC region. Skilled immigrants from other sub-Saharan African countries perceive Lesotho as having relatively better economic conditions than their own countries. Secondly, Lesotho serves as a convenient transit country to South Africa, seen by many Africans as the 'Europe' of the continent. The increasing number of immigrants in Lesotho in recent years has generated debates about the contribution of foreigners to national development. This article seeks to contribute to this debate by counteracting the emerging perception that depicts immigrants as a total liability to Lesotho. The immigration debate is assuming a new height of intensity, as conventional

\footnotetext{
${ }^{1}$ University of Cape Town, South Africa.

${ }^{2}$ The Sesotho terms makoerekoere, makhooa and makula are used derogatorily in Lesotho to refer to African, white and Indian immigrants respectively. However, the exact meaning or origin of makoerekoere, which is more popularly used, seems elusive. Some claim that it refers to black foreigners, while others maintain that the term is used to describe the rattling sound of languages spoken by African immigrants. For a more detailed discussion of the origin and use of the term, see Sichone (2002).
} 
theories do not regard immigrants as citizens. Yet citizenship is not sacrosanct; various forces are slowly but surely questioning its original relevance. In the next section the concept of citizenship and the threat facing citizenship are analysed.

\section{CITIZENSHIP AND ITS EMERGING CHALLENGES}

Citizenship as understood in contemporary discourse is linked to the state. The modern state is a legal entity, defining definite internationally recognised territorial boundaries, with a population, an economic system, coercive apparatus for enforcing authoritative decisions, and sovereignty in its internal and external dealings (Russett \& Starr, 1988: 49-50). Individuals recognised by law to belong to that particular territorial expression are regarded as citizens and enjoy unfettered entitlements to the rights and privileges accorded by the state.

Historically, the concept of citizenship predated the state. Borja (2000) contends that the citizenship originally referred to the status of free men and women in the city who elected councillors and members of other lower administrative machines. He notes that the citizen was the de jure member of the city as opposed to the de facto population of the municipality. With the emergence of states, however, cities were subsumed in the larger political entities. Today, citizenship is used expressly and exclusively in relation to the state. The status of citizenship also defines an individual's nationality. Yet a state may comprise a number of nations, or group of people claiming common history, beliefs and traditions (Plano \& Olton, 1988: 3); and nations often transcend state borders, overlapping into neighbouring and distant political entities. Accordingly, the term 'nation-state' is used to describe the internationally recognised territory. It is also common to conflate citizenship with nationality. Citizenship defines the connection of individuals to the state and gives its citizens a particular identity and privileges denied to non-members of the state, variously referred to as foreigners, immigrants or aliens.

Citizenship is associated with rights and privileges accorded by the state. These include political and civic rights - the right to vote and be voted for; economic and social rights - the right to employment, housing and social security; as well as the rights and protections enshrined in the Universal Declaration of Human Rights (United Nations, 1948). But historically these rights have not been automatically guaranteed. Indeed, until the mid-twentieth century, citizenship could not be regarded as an automatic civil status. The enjoyment of rights has in many countries resulted from painful and prolonged struggles waged by marginalised communities.

Today, however, citizenship and its attendant rights have been established as automatic for nationals, irrespective of gender or race. Nevertheless, while citizenship has become unconditional and a matter of course, it is increasingly contending with forces that undermine the state's monopoly over its definition and suggest a need for its reconstruction and redefinition. Globalisation threatens the notion of citizenship. It increasingly creates a system where borders become anachronistic, and promotes regional organisations and common markets. These supra-national states assume some of the roles of the traditional state. Moreover, globalisation facilitates international migration, in turn creating multicultural societies, and the acquisition of dual nationality by immigrants who do not wish to lose the citizenship of their original countries of residence. Cumulatively, these factors undermine the monopoly of the state over its citizens. Citizenship, as Scobey (2001: 13) notes, is in crisis and gradually becoming endangered. However, citizenship still remains a basis for denying rights and privileges. These jealously guarded 
rights and opportunities may underlie antipathy for foreigners, who are often perceived as potential competitors. There is a natural escalation of hatred for immigrants in countries where economic opportunities are shrinking. Facing the reality of declining economic opportunities, rising anti-foreigner sentiments have become inevitable in Lesotho.

\section{LESOTHO IN PERSPECTIVE}

Lesotho is a landlocked country. About 86 per cent of Basotho are engaged in agriculture, yet the country has only $30 \mathrm{~km}^{2}$ of irrigated land. Farming and cattle-rearing, the dominant agricultural activities, depend on the mercies of the rain. Erratic rainfall and drought have often devastated Lesotho's agriculture. Accordingly, over 80 per cent of Lesotho's food requirements are obtained externally, mostly from South Africa. Lesotho has a fragile industrial base with most of its few industries owned by South Africans, Indians and Chinese. Lesotho has not been able to attract much foreign direct investment in recent years and thus grapples with an industrial growth rate of 15,5 per cent. Although a high rate by African standards, the increase in industrial production is insignificant in relation to Lesotho's annual population growth of 2,9 per cent. Consequently, unemployment has risen dramatically, and is currently estimated at around 45 per cent. This makes Lesotho second only to Mozambique (with an unemployment rate estimated at 47 per cent) in the whole of Africa (Nkosi, 2002: 15; Africa Information Centre, 2002).

Lesotho has a narrow revenue base on account of its weak agricultural and industrial establishments. Customs duties, migrant remittances and, to a lesser extent, tourism have been the country's traditional sources of revenue (Central Bank of Lesotho, 1997: 33). Migrant remittances are also key sources of revenue. Since the 1960s about a quarter of Lesotho's population of working age (approximately 100000 ) have been employed in South Africa, mostly in the mines (Matlosa, 1996). In 1990, migrant remittances added 67 per cent to the country's GNP. The number of Lesotho migrant workers has, however, declined steadily since the early 1990s following massive retrenchments in the South African mines, and migrant remittances have fallen to only 33 per cent of GNP (Mhlanga, 1996; Transformation Resource Centre, 1996). Like many sub-Saharan countries, Lesotho relies heavily on foreign aid, which has increased its indebtedness. Although its external debt of $\$ 735$ million (2002) is small compared to other African countries, it is nevertheless worrisome given the small size and the fragility of the country's economy. These attributes clearly give a picture of a country located precariously in economic terms; in which 50 per cent of the population is classified as living below the poverty line and barely surviving at the margins (UNDP, 2000: 171).

The Lesotho Highlands Water Project (LHWP), a tripartite venture involving the governments of Lesotho, South Africa and the World Bank provided a lifeline to the Lesotho economy. The project, which supplies water to South Africa, benefits Lesotho in various ways (Matlosa, 2000). South Africa pays royalties to the Lesotho Government, which account for 25 per cent of the country's export revenue, 14 per cent of government revenue and 5 per cent of GDP (LHDA, 1996: 5). The LHWP also generates employment and makes Lesotho self-sufficient in power. However, the LHWP did not generate sufficient jobs to absorb the thousands of unemployed Basotho. In fact, with the completion of the Katse and Mohale Dams, workers employed during the construction phases were retrenched. The LHWP thus only temporarily eased the country's unemployment pressures. Against this background and the truism that a dominant motive 
for voluntary migration is economic - to seek employment and better remuneration the critical question is why would a country with little or no employment prospects, even enough for its own nationals, attract immigrants? Or simply put, why is Lesotho a receiving country? This is a perplexing question we address next.

\section{EXPLAINING MIGRANCY TO LESOTHO}

There are various categories of immigrants in Lesotho. These include professionals whose skills are in short supply in Lesotho, many of whom work on contract for the government or related institutions. A second category of immigrants includes artisans and migrants, and small-scale traders who stay for a few weeks, sell their wares and then return home. These informal cross-border trading migrants return into Lesotho with new stocks and continue their cycle of entry and exit (Akokpari, 1999: 83-4). Some migrants in this category are undocumented, making accurate estimates of their numbers difficult. A third category of immigrants is made up of the business people who establish industries, private retail shops and other commercial ventures, and usually stay longer in the country. However, the political atmosphere tends to dominate their views on the security of their ventures, and they are ready to wind up their businesses at the smallest threat of political turmoil and uncertainty. Strange (1991: 42) suggested that often 'it is the search for security more than the pursuit of profit, that motivates firms to engage in international production'. A fourth group of foreigners includes the accredited representatives of international organisations, staff of foreign diplomatic missions and external experts or advisers.

However, irrespective of the level of skills or educational attainment, immigrants can be formal (or documented) and possess valid immigration documentation; or informal (or undocumented), without valid entry documentation. The latter are often referred to as 'illegal' immigrants. ${ }^{3}$ Professionals and other skilled immigrants tend to be formal immigrants, while non-professionals often, but not always, tend to be informal immigrants. Estimates of the number of immigrants in Lesotho are difficult to make because of the lack of accurate records. Between January 1998 and April 2002 the Lesotho Immigration Department issued a total of 2573 residence permits, with a duration of one to two years (Lesotho Immigration Department, 2002).

A further typology of immigrants in Lesotho, as in other receiving countries, is based on the reasons for their leaving their countries of origin. Immigrants who leave their original countries in response to conflicts, political oppression and environmental disasters are referred to as forced migrants. International conventions classify these as refugees (OAU, 1969). Those emigrating out of discretion are generally referred to as voluntary or economic migrants, who relocate in other economically more viable countries. During the apartheid years Lesotho received a large number of refugees who were mainly black South Africans waging the war of liberation. However, most foreigners currently in Lesotho are voluntary migrants, mainly professionals (Gay, 2000).

Various reasons account for the influx of immigrants into Lesotho. In the first place, the relatively better remuneration packages offered by formal employers have been a source of attraction to skilled immigrants. Remuneration for workers in health and educational

\footnotetext{
${ }^{3}$ There is a growing concern about the use of the term 'illegal' to describe immigrants without valid documentation (Akokpari, 2000). Among other things the term is derogatory and tends to depict such individuals as criminals. Not all immigrants without valid documents are criminals, nor can it safely be said that immigrants with valid documents will not engage in criminal activities. A preferred term is 'undocumented'.
} 
institutions is higher than in similar establishments in other sub-Saharan African countries, except in such SADC countries as Botswana, Namibia, South Africa and Swaziland. Skilled individuals migrate to Lesotho and to the relatively affluent SADC countries. Lesotho's ability to offer relatively competitive remuneration has to be understood within the broader context of the country's economic and monetary ties with South Africa. The Southern African Customs Union (SACU), established in 1910, includes Lesotho; and the Common Monetary Area (CMA), established in the mid-1970s, ties the currencies of Lesotho, Namibia and Swaziland to that of South Africa and gives them a stronger currency vis-à-vis the dollar. However, it increases the country's susceptibility to volatility in the rand. Depreciation of the rand between 2001 and 2002 weakened Lesotho's ability to attract professionals as salaries fell in dollar terms, while some professionals previously employed in Lesotho returned home or left for Botswana and South Africa. During 2001 and much of 2002 nearly half the Nigerian academics, who constituted the bulk of the expatriate community at the National University of Lesotho, returned home following substantial upward adjustments in salaries by the new Nigerian civilian government.

There is a chronic shortage of qualified personnel to fill vacant posts in the public and corporate services in the country. The National University of Lesotho relies on expatriates to fill senior positions. In the 1999/2000 academic year eight of the nine professors in the university were expatriates, as were six of the 11 associate professors and 33 of the 62 senior lecturers. Only among junior lecturers did locals outnumber expatriates (National University of Lesotho, 2002: 18). Trained Basotho often prefer employment at much higher salaries in South Africa. Cultural similarities and family relationships across the border make it easier for Basotho to find openings in South Africa, and qualified Basotho academics left for South Africa in increasing numbers following the new political dispensation in 1994 (Matlosa, 1999a). This 'brain drain' from Lesotho made it imperative for the university to accept foreign academics. This has been accentuated by resignations of local academics from the university to join the private or public sector. Table 1 shows that 36 academics resigned in the five-year period between the 1994/95 and 1998/99 academic years. Setsabi (2003) noted the loss of 25 of the 268-member teaching staff during the 2001/2002 academic year alone. In an institution with a chronic shortage of staff, the loss of even one member might prove ruinous for a department.

Diploma-awarding tertiary institutions and high schools, particularly those located in the rural areas, also have a recurrent need for immigrant teachers. The Teaching Service

Table 1: Rate of resignation of academic staff at the National University of Lesotho, 1994/95-1998/99

\begin{tabular}{lcc}
\hline Year & Number of local staff & Number resigning \\
\hline $1994 / 95$ & 155 & 9 \\
$1995 / 96$ & 130 & 4 \\
$1996 / 97$ & 194 & 12 \\
$1997 / 98$ & 194 & 7 \\
$1998 / 99$ & 194 & 4 \\
Total & & 36 \\
\hline
\end{tabular}

Source: Matlosa, 1999a: 8, and National University of Lesotho Development and Planning Office, 2001: 19. 
Department (TSD) of the Ministry of Education reported that 267 of the 3200 high school teachers nationwide in 2002 were expatriates, the majority of whom were Indians, Ugandans, Ghanaians and Nigerians (Lesotho TSD, 2002).

Many Basotho health workers too, including doctors, dentists and nurses, have migrated to South Africa (Transformation Resource Centre, 1989) and a number of skilled posts had to be filled by immigrants. In mid-2002, 76 of the 109 doctors in the country, or nearly 70 per cent of all doctors, were foreigners (Lesotho Ministry of Health and Social Welfare, 2002).

Some immigrants come to Lesotho not as an ultimate destination, but as a transit country to Europe or South Africa. Some have succeeded in reaching South Africa via Lesotho because of the artificiality but also the porosity of the border between the two countries, which has facilitated the crossing of especially undocumented immigrants into South Africa in recent years (Akokpari, 2000). Lesotho's relaxed, often less stringent, immigration policies make it easy for African immigrants to get into the country before crossing over into South Africa.

Controlling the incidence of undocumented and transit immigrants is a real challenge for Lesotho, not only because the country lacks the necessary infrastructure, but also because it cannot maintain embassies in most African countries. Lesotho has embassies in only three of the 53 countries in Africa: Egypt, Ethiopia and South Africa. Immigrants from other countries visit Lesotho without visas. They are usually allowed in and given between 14 and 30 days to regularise their stay with the Immigration Department. Some immigrants abuse this privilege.

Immigrants who enter Lesotho with the aim of establishing economic ventures include Chinese, Indians and South Africans, who own the bulk of the industries and shops in the country. The arrival of Indians dates back to the 1880s (Gill, 1993: 143). Some came directly from India, while others arrived through South Africa. Chinese migration is much more recent, and had nevertheless become a formidable economic community in Lesotho by the mid-1980s. The Chinese have established and own businesses in most of the commercial towns of Lesotho, in which many Basotho are employed (Gill, 1993: 244-45). Most of the South African business owners in Lesotho reside across the border either in Ladybrand, some ten kilometres from the Lesotho capital, Maseru, or in Ficksburg, some three kilometres from Maputsoe, another industrial centre of Lesotho.

The current immigration regime in Lesotho is receptive to migrants promising to start economic ventures and Lesotho has received a large number of such business-oriented immigrants in recent years. The National Employment Service issued or renewed 2743 work permits to nationals of over 30 different countries in 2000; 1228 of these went to Chinese, 542 to South Africans and 203 to Indian migrants. In the following year 2351 work permits were issued, 1146 to Chinese, 583 to South Africans and 143 to Indians (Lesotho National Employment Service, 2002).

Creating an immigration policy friendly to foreigners with business intentions has been necessitated by Lesotho's privatisation programme, forced on the country by international organisations. This has been responsible for massive labour retrenchments in the public sector, which threaten the country's political stability and breed crime, violence and insecurity. The huge number of unemployed Basotho has been increased by large-scale retrenchments in the South African mining industry. A total of 106379 Basotho were employed in the South African mines in 1986, but only 93319 in 1991 
and 60000 in 2000 (Mhlanga, 1996; TEBA, 2001). These retrenchments have hit hardest countries such as Lesotho, which depend heavily on migrant remittances. Migrant remittances had helped not only the Lesotho government through the compulsory deferred payment $(\mathrm{CDP})^{4}$ system, which brought in much-needed revenue, but also the many Basotho who depended on it for basic sustenance. ${ }^{5}$ The combined effect of privatisation and retrenchment have exacerbated unemployment in Lesotho; in response the immigration regime has become all the more receptive to those immigrants who might prove to be private entrepreneurs.

Globalisation is likely to put fragile and nascent industries out of business and thus throw many more Basotho out of employment (Akokpari, 2001). Some unemployed Basotho might find solace in the expansion of the paltry informal sector; but once again, globalisation enhances the necessity of friendly immigration policies towards immigrants who are likely to create jobs. The influx of immigrants has become a source of debate and speculation about their relevance to national development. The concern about immigrants, however, seems to relate more to black African foreigners and, to some extent, Chinese, rather than whites or Indians.

\section{THE IMMIGRATION POLEMICS}

Immigration has become a major public issue. In Lesotho, however, no systematic studies on nationals' attitudes exist, which hampers attempts to draw firm conclusions on public opinion on immigration. It is nevertheless apparent that immigration has become a highly topical and delicate issue.

Election years often provide auspicious timing for anti-immigration politicians to manipulate the sentiments of the electorate, especially if the elections coincide with periods of economic difficulties On 30 April 2002, Mr Sephiri Motanyane, the Secretary-General of the ruling Lesotho Congress for Democracy (LCD) and Minister of Tourism, Sports and Culture, reiterated the determination of the party to rid the country of unwanted immigrants if it was re-elected. Similarly, Mr Molapo Qhobela, a leading opposition politician, and leader of the revived Basutoland African Congress (BAC), vowed to re-register all immigrants and to reverse the country's well-advanced privatisation programme if his party came to power (LENA, 2002: 2). These sentiments are indicative of growing public concern about immigrants and attempts by politicians to exploit anti-foreigner feelings. Public enterprises liquidated under Lesotho's privatisation drive always found new ownership in non-Basotho media houses have waged antiimmigrant campaigns. ${ }^{6}$ Generally, the debate on immigration features two diametrically opposed views, each projecting distinctive arguments.

\footnotetext{
${ }^{4}$ The system of compulsory deferred payment (CDP) was introduced in 1976 through a bilateral agreement with the South African government. Initially, 60 per cent of migrants' wages would be paid to them through the Bank of Lesotho in Maseru. This was reduced to 30 per cent in 1991 following repeated complaints by the migrant miners. This process generated muchneeded revenue for the Lesotho government through the payment of interest. It was estimated that CDP to Lesotho amounted to R444 million, R264 million and R276 million in 1990, 1991 and 1995, respectively (Matlosa 1996: 181-2).

${ }^{5}$ Coplan \& Thoalane (1994) estimate that on average one migrant miner supports between 10 and 15 dependants.

${ }^{6}$ The Maseru-based Sesotho newspaper, Moafrika, and the Moafrika radio station are known to have been fanning anti-immigrant, especially anti-Chinese, sentiments. So persistent have the newspaper and the news station been that the chairman of the media freedom organization was forced to express his disgust publicly about that practice (Selinyane, 2002: 8).
} 


\subsection{The case against immigration}

In nearly every country, those opposed to immigration tend to be the more vociferous, irrespective of their numerical strength. Advocates of immigration, especially politicians, may fear being branded anti-national or unpatriotic. It is virtually unthinkable that a politician in any African country which attracts immigrants should publicly declare a pro-immigration position. By contrast, anti-foreigner and right-wing politicians sensationalise incidents and manipulate anti-immigration sentiments as a way of ingratiating themselves to the population. There are no organised anti-immigration activists on a national scale in Lesotho, yet anti-foreigner sentiments are evident among sections of the population.

It is often claimed that immigration takes jobs away from nationals and thus intensifies unemployment. So widespread is this belief in Lesotho that it has led to strong antiimmigrant sentiments, reminiscent of the xenophobia prevalent in South Africa (Akokpari, 2002; Sichone, 2002). The validity of the claim that foreigners cause job losses has to be evaluated in context. No government employs expatriates to displace and replace its nationals. In every country, priority is accorded nationals in matters of employment. Expatriates are employed only when vacancies exist and local skills are lacking. When no suitable locals are available to fill posts, standards and efficiency may be compromised unless qualified expatriates are hired, although locals may perhaps lose jobs to foreigners in sectors where few or no specialised skills are required. The hysteria about immigrants often arises when a country faces economic difficulties and when it is (falsely) believed that jobs will be 'freed' once foreigners are expelled. However, this assumption has hardly been validated anywhere in Africa. When thousands of immigrants, mostly Nigerians, were expelled from Ghana in 1969, and when millions were deported from Nigeria in 1983 and again in 1985 in response to unemployment crises, this scarcely reversed the economic situation (EssumanJohnson, 1996: 68-9). On the contrary, the short- to medium-term consequences of a sudden expulsion of labour is a decline in production and a deepening of the economic crisis, especially where specialised skills are required.

Foreigners are believed to introduce or escalate crime. Many criminal activities have involved immigrants, especially crimes of money laundering, drug trafficking, the possession of fraudulent documents, and have gained national and international notoriety. Nigerians are looked upon with suspicion and mistrust for drug peddling, fraudulent deals and wily business transactions including the '419' circular letter scam (after the Nigerian penal code reference to fraud schemes), which 'consists of luring unsuspecting businessmen (both local and foreign) with fake deals and them robbing them' (Nyamnjoh, 2000: 14-15). In April 2002, the South African Police Service broke up a R43 million scam involving Nigerians (Padayachee, 2002: 3). Eighteen Nigerians were ordered out of Lesotho between January and December 2002, mainly for the fraudulent acquisition of Lesotho passports with which to enter the United States, the United Kingdom and other European Union countries (Lesotho Immigration Department, 2002).

Chinese, who have also been known to engage in fraudulent business deals, have also crossed the Lesotho immigration authorities. Recently four Chinese were deported for overstaying their visas or for unlawfully obtaining manufacturing licenses (Lesotho Immigration Department, 2002). Chinese in particular have acquired a reputation as exploitative, arrogant and disrespectful of the rights and comfort of their local employees. Chinese factory owners take advantage of the abundance of labour to pay low wages 
and to threaten local workers with dismissal at the least hint of agitation. Many local employees have borne the pain and indignity of Chinese exploitation in silence (Lesaoana, 1999). Moreover, Chinese are frequently associated with the production or sale of inferior goods. The eagerness of Chinese to enter into business ventures and their rapid rate of migration into Lesotho are raising fears that they may become a dominant economic constituency and be capable of dictating terms to the Basotho. These convictions seem to have made the Chinese and their ventures frequent targets of attack.

There has been a growing tendency for Lesotho nationals to perceive immigrants as criminals and ignore the different categories, nationals and skills of immigrants. It may, be misleading, even dangerous, to depict all immigrants of a particular nationality, skill level or occupation as potential criminals.

The uncritical suspicion that immigrants are carriers of dreadful diseases such as HIV/ AIDS is rapidly gaining currency among the youth and the less informed sections of the Lesotho population. Immigrants are potential transmitters of diseases, including curable diseases, because of their inability, and often unwillingness, to access health services. This is particularly the case with undocumented immigrants who engage in the sex trade and who are under the constant fear that visiting health centres could expose them to the police and immigration officers. However, there is little compelling evidence to substantiate the claim that immigrants are the principal carriers of such diseases. There are no systematic studies linking incidences of HIV/AIDS in Lesotho to foreigners, but Basotho migrant workers in South Africa have been linked to the spread of the virus in reports and studies (Lesotho Ministry of Health and Social Welfare, 2000: 12-13; GOL, 2000; Sadie et al., 1993). Despite the hysteria about immigrants spreading HIV/AIDS in Lesotho, this has not been borne out by evidence.

Another, but by no means trifling, reason for the anti-immigrant campaign is the feeling that immigrants may compromise the homogenous character of the Basotho nation. Concerns about tarnishing the peculiar identity of a nation are universal and are expressed even by nationals of countries known to be among the most generous recipients of immigrants (see Brimelow, 1995, on the United States and BBC, 2002, on the United Kingdom). In Lesotho, these fears are underpinned by intermarriage between male immigrants and Basotho women. These children of these marriages, whether genuine or marriages of convenience, may legally have Basotho nationality, but may in practice face a fundamental crisis of identity. Many immigrants, too, acquire Lesotho citizenship by naturalisation. All this may ultimately challenge the homogeneity in the Basotho nation. Meanwhile globalisation is rapidly undermining the identity of states and nations and dual citizenship is increasingly being adopted by African countries (although not by Lesotho) and helping to create multi-ethnic communities which render the traditional homogeneity of nations obsolete.

There is disquiet about immigrants who may swell the population of the host country unendurably and exert additional strain on meagre and overstretched resources. Here a distinction has to be made between voluntary and forced migrants. The bulk of the foreigners in Lesotho, as noted earlier, are economic migrants who possess one sort of skill or another, who can engage in wage employment and live decently. Gay (2000: 67) shows that over 90 per cent of immigrants in Lesotho have either a first or higher degree, and are therefore capable of engaging in highly skilled jobs and paying income taxes. Such skilled immigrants can scarcely constitute a liability to the 
Lesotho state. Moreover, most immigrants seek to accumulate savings and return to their countries of origin. Studies in South Africa show that over 90 per cent of immigrants have no intention of residing there permanently (Johnson, 1998; Mattes et al., 1999). A similar percentage of immigrants to Lesotho hope eventually to return to their home countries. The majority of immigrants in Lesotho, like those in South Africa, are 'migrants' rather than immigrants (Gay, 2000: 72).

Most of the arguments used to justify anti-immigrant sentiments are weak, if not fundamentally flawed. They are often evoked to serve particular interests, or to score political points. In many countries in Africa, including Lesotho and South Africa, immigrants are unnecessarily targeted, preyed upon and made scapegoats often because they are strangers in a strange land.

\subsection{The case for immigration}

Anti-immigration activists are not always right in their claims and often refuse to acknowledge the practical contribution of immigrants to the development of the host country. Without systematic documentation of the role of immigrants in Lesotho's economy, anti-immigrant sentiment flourishes on ignorance. Immigrants are credited with creating most of the new private sector jobs in Lesotho in recent years. Many Chinese, Indian and South African immigrants own the larger-scale industries in Lesotho. Some immigrants establish schools, health clinics and hotels in which various numbers of Basotho are employed. In addition foreigners run retail shops, garages and car repair workshops, hairdressers and other artisan ventures, and employ a sizeable number of Basotho. An accurate number of Basotho employees in these small-scale immigrant-owned businesses is difficult to ascertain, by the National Employment Service, because the entrepreneurs tend to overstate the number of locals they employ in order to facilitate the renewal of work permits.

In the Ha Thetsane industrial area, the largest industrial centre in Lesotho (the other four being Mafeteng, Mohale's Hoek, Maputsoe and the Maseru industrial area), 16 registered companies were operating by mid-2002 and employed a total of 9709 Basotho. Thirteen were owned by foreigners - from China, Taiwan, South Africa and Pakistan - and employed 8227 locals (Lesotho Ministry of Trade and Industry, 2002). The locally owned industries employed 1200 Basotho.

Lesotho faces acute unemployment problems and the post-election disturbances of 1998, in which angry mobs of opposition supporters looted and burned down shops and businesses owned by immigrants, seriously reversed the country's earlier gains in employment creation. The cost of burning businesses in the country's commercial towns such as Maseru, Mafeteng, Mohale's Hoek and Butha-Buthe was estimated at R160 million. The number of firms either vandalised or totally burned down was estimated at 246, while the number of Basotho who lost their jobs as a result of the combined effects of the looting or burning of businesses, the creation of an insecure investment climate and the consequent winding-up of some business ventures, was no less than 4000 (GOL, 1998: xi; Matlosa, 1999b: 189).

Immigrants bring into Lesotho much-needed skills, which are otherwise in short supply. Many health and educational establishments in Lesotho employ large numbers of immigrants. In the National University of Lesotho, for example, no less than 25 per cent of the academic staff consisted of expatriates in the period between 1995/96 and 1999/2000 (Table 2). 
Table 2: Academic staff of the National University of Lesotho by nationality, 1995/96-1999/00*

\begin{tabular}{lcccc}
\hline Year & Locals & Expatriates & Total & $\begin{array}{c}\text { Expatriates as } \\
\text { percentage of total }\end{array}$ \\
\hline $1995 / 96$ & 130 & 72 & 202 & 35 \\
$1996 / 97$ & 194 & 63 & 257 & 25 \\
$1997 / 98$ & 194 & 64 & 258 & 25 \\
$1998 / 99$ & 194 & 64 & 258 & 25 \\
$1999 / 00$ & 183 & 66 & 249 & 27 \\
\hline
\end{tabular}

*These figures exclude employees in administration, the library, the university's international school and the Pre-Entry Science Programme.

Source: National University of Lesotho, 2001: 19.

Many other educational and health institutions employ large numbers of expatriate professionals. Other skills imported into Lesotho by immigrants include computer and telecommunication technology, production and managerial expertise (Tables 3 and 4). Immigrants temporarily relieve the manpower shortage of the country. In the long term, Basotho must acquire the relevant skills from immigrant professionals so that ultimately the skill crisis in the country can be alleviated.

Immigrants play an often discounted or unobtrusive role in raising the regional, but especially the international, competitiveness of the country. As these immigrants bring such skills to bear on the general developmental efforts of the host country, they raise the international competitiveness of the host country in the areas of health, education, science and technology. In Canada and the United States leading recipients of immigrants fully attuned with globalisation, well-orchestrated strategies are in place to tap the expertise of immigrants. Canadian universities make provision for international students who study for advanced degrees to teach or undertake research in Canada for a year upon completion of their programmes and prior to returning to their home countries, irrespective of how this higher education was financed. This enables Canada

Table 3: Number of work permits issued by major occupational group, 2001

\begin{tabular}{lc}
\hline Occupational group & Permits issued \\
\hline Legislator, senior officials and managers & 1140 \\
Professionals & 386 \\
Technicians & 366 \\
Clerks & 9 \\
Service workers, shops and sales workers & 63 \\
Craft and related traders & 8 \\
Plant machine operators and assemblers & 99 \\
Elementary occupations & 280 \\
Not elsewhere classified & 0 \\
Total & 2351 \\
\hline
\end{tabular}

Source: Lesotho National Employment Service, 2002. 
Table 4: Number of work permits issued by major industrial group, 2001

\begin{tabular}{lr}
\hline Industrial group & Permits issued \\
\hline Mining and quarrying & 10 \\
Manufacturing & 923 \\
Electricity, gas and water supply & 19 \\
Construction & 389 \\
Wholesale and retail trade, repair of motor & 627 \\
$\quad$ vehicles, and motorcycles, personal & \\
$\quad$ household goods & 25 \\
Hotels and restaurants & 7 \\
Transport, storage and communication & 13 \\
Financial intermediaries & 230 \\
Education & 78 \\
Health and social work & 30 \\
Other community work & 0 \\
Real estate, renting and business & 2351 \\
Total & \\
\hline
\end{tabular}

Source: Lesotho National Employment Service, 2002.

to benefit from the skills acquired by these graduates. The United States government has in place a yearly quota-based lottery system through which it selects and admits skilled immigrants. Closer to home, in South Africa, the anti-immigration public opinion of the immediate post-apartheid years is being replaced by a more pragmatic policy of selective admission of immigrants whose skills are in short supply. For South Africa, this is particularly critical as large numbers of its mainly white professionals emigrate to Australia, New Zealand and elsewhere (Brown et al., 2000). All these policies are pursued in an attempt to elevate the competitiveness of these countries.

Finally, the international profile of Lesotho can be raised significantly by the admission rather than the exclusion of immigrants. Australia, Canada, the Netherlands, Italy, the United Kingdom and the United States, which contend on a daily basis with migrants documented and undocumented - have acquired a special international reputation of being receptive to immigrants. Although Lesotho may see little relevance in this virtue, because of its incapacity to accommodate a large influx of immigrants, it can derive important international credit for being open to immigration.

Thus, on a cost-benefit scale, the advantages of immigration for Lesotho seem to outweigh its disadvantages by far. In the areas of economics, education, medicine, entrepreneurship and technology, immigration is an asset, rather than a liability, to Lesotho which, like many sub-Saharan African countries, is grappling with the challenges of development.

\section{CONCLUSION}

Immigration has become a contentious issue in many countries, including Lesotho. Lesotho would not normally be a receiving country in terms of its ability to offer 
employment. However, it is seen as a country with relatively better economic opportunities, and as a transit country to South Africa, and these have elevated it as a destination for professionals from other sub-Saharan African countries. Lesotho's strong economic and monetary ties with South Africa are key reasons for its ability to offer competitive remuneration packages.

The influx of immigrants into Lesotho, although is on a much lesser scale than to South Africa, has generated anxieties and polemic. These debates are rooted in or informed by the notion of citizenship, which confers exclusive rights and privileges on individuals considered to belong to the state or described in law as citizens. However, there are powerful forces which undermine the state's sovereign status and its previously unquestioned monopoly over citizens. Globalisation, as noted, is certain to render anachronistic the notions of the state and citizenship.

The immigration debate in Lesotho is particularly fascinating because in spite of strong anti-foreigner sentiments, the immigration regime is receptive to foreigners. Antiimmigration arguments generally cite immigrants competing for jobs with nationals, increasing the crime rate, undermining the homogeneity of the nation; and intensifying pressure on the country's resources. This article has attempted to demonstrate the limits of these arguments by indicating that these rely on sentiment rather than facts. Although pro-immigration positions are not publicised, the facts are compelling: immigration creates rather than compromises jobs; it brings in skills that are in short supply in various sectors of the economy; it raises the international competitiveness of the receiving country and raises the international image of the host country. Many of the receiving countries in the industrial north continue to be receptive to immigrants because they desire to obtain benefits from them.

It seems appropriate to suggest that it is in the interest of Lesotho and its developmental efforts to welcome rather than to exclude immigrants, especially skilled immigrants. The poverty of the Lesotho economy makes the country unable to offer remuneration packages comparable to those in neighbouring South Africa. And as long as these wage disparities exist, Lesotho will continually suffer a brain drain from which South Africa gains. Skilled labour shortages in Lesotho will in turn compel the country to depend on immigrants. Herein lies the contribution of the 'strangers' to Lesotho's development.

\section{REFERENCES}

AFRICA INFORMATION CENTRE, 2002. Country profile: Kingdom of Lesotho, accessed 10/2/2002. http://www.hmnet.com/africa/1africa.html

AKOKPARI, JK, 1999. The political economy of migration in sub-Saharan Africa. African Sociological Review, 3(1): 75-93.

AKOKPARI, JK, 2000. Globalization and migration in Africa. African Sociological Review, 4(2): 72-92.

AKOKPARI, JK, 2001. Globalization and the challenges for the African state. Nordic Journal of African Studies, 10(2): 188-209.

AKOKPARI, JK, 2002. International migration, xenophobia and the dilemma of the South African state. In Buthelezi, S \& Le Roux, E (Eds), South Africa since 1994: lessons and prospects. Pretoria: Africa Institute of South Africa, pp. 221-46.

BORJA, J, 2000. The citizenship question and the challenge of globalization. City, 4(1): $43-52$. 
BRIMELOW, P, 1995. Alien nation: common sense about America's immigration disaster. New York: Random House.

BRITISH BROADCASTING CORPORATION (BBC), 2002. News Online Special Report: May 20-31. http://news.bbc.co.uk/hi/english/uk_politics/newsid_1993000/ 1993597.stm

BROWN, M, KAPLAN, D \& MAYER, J, 2000. An outline of skilled emigration from South Africa. Africa Insight, 30(2): 41-47.

CENTRAL BANK OF LESOTHO, 1997. Annual report. Morija: Morija Printing Works. COPLAN, D \& THOALANE, T, 1994. Motherless households, landless farms: the social implications of changing employment patterns among Lesotho migrants. Migrant Labour Working Paper no. 18. Ottawa: International Development Research Centre (IDRC).

ESSUMAN-JOHNSON, E, 1996. Refugees and migrants in West Africa. Faculty of Social Studies (FASS), University of Ghana. FASS Bulletin, 1(1): 64-73.

GAY, J, 2000. Migration attitudes of skilled professionals in Lesotho. Africa Insight, October: $65-74$.

GILL, SJ, 1993. A short history of Lesotho. Morija: Morija Printing Works.

GOVERNMENT OF LESOTHO (GOL), 1998. Interim Political Authority (IPA) Act. Maseru: Government of Lesotho.

GOVERNMENT OF LESOTHO (GOL), 2000. Policy framework on HIV/AIDS prevention, control and management. Maseru: Government of Lesotho.

JOHNSON, A, 1998. 'Go Back to your Country'. Mail and Guardian, Johannesburg, 26 June.

LESAOANA, JM, 1999. The impact of multinational corporations on developing countries: a case study of the Chinese garment manufacturing company in Lesotho. Research project submitted to the Department of Political and Administrative Studies, National University of Lesotho, in partial fulfilment of the requirements for the Bachelor of Arts Degree, May.

LESOTHO HIGHLANDS DEVELOPMENT AUTHORITY (LHDA), 1996. Presentation to the NGO workshop on the Lesotho Highlands Water Project. Johannesburg, 29-30 August.

LESOTHO IMMIGRATION DEPARTMENT, 2002. Files and Records. Maseru: Lesotho Immigration Department.

LESOTHO MINISTRY OF HEALTH AND SOCIAL WELFARE, 2000. Sexually transmitted infections, prevention and control programme: Annual Report. Maseru: Government of Lesotho.

LESOTHO MINISTRY OF HEALTH AND SOCIAL WELFARE, 2002. Files. Maseru. LESOTHO MINISTRY OF TRADE AND INDUSTRY, 2002. Statistical Report. Maseru: Ministry of Trade and Industry.

LESOTHO NATIONAL EMPLOYMENT SERVICE, 2002. Statistical Report. Maseru: Ministry of Labour and Employment.

LESOTHO NEWS AGENCY (LENA), 2002. BAC will reverse privatization programme. Public Eye (Maseru): 6(11): 15-21 March.

LESOTHO TEACHING SERVICE DEPARTMENT (TSD), 2002. Files. Maseru.

MATLOSA, K, 1996. The future of Basotho migrant miners in post-Apartheid South Africa: rethinking Lesotho's regional identity. Lesotho Law Journal, 9(2): 169-91.

MATLOSA, K, 1999a. Brain drain and tertiary education in Lesotho: implications for the National University of Lesotho. Paper presented at a regional workshop on Relevance and Quality of University Teaching and Research in Formulation and Implementation of 
Societally Sustainable Development Programmes, Maseru Sun Hotel, Maseru, 24-26 August.

MATLOSA, K, 1999b. Conflict and conflict management: Lesotho's political crisis after the 1998 election. Lesotho Social Science Review, 5(1): 163-96.

MATLOSA, K, 2000. The Lesotho Highlands Water Project: Socio-economic Impact. In Tevera, Daniel \& Moyo, Sam (Eds), Environmental Security in Southern Africa. Harare: Southern African Regional Institute for Policy Studies (SARIPS), pp. 175-86.

MATTES, R, TAYLOR, DM, MCDONALD, DA, POORE, A \& RICHMOND, W, 1999. Still waiting for the barbarians: SA attitudes to immigrants and immigration. Southern Africa Migration Project, Migration Policy Series, no. 14. Cape Town: Institute for Democracy in South Africa (IDASA).

MHLANGA, M, 1996. Declining migrant incomes and remittances: effects and repercussions and possible implications for the Mafeteng Development Project. Business Support Southern Africa (Maseru), March.

NATIONAL UNIVERSITY OF LESOTHO, 2001. Development and Planning Office. National University of Lesotho Annual Statistical Bulletin. Roma: National University of Lesotho.

NKOSI, S, 2002. Mountain Kingdom still a land divided. Sunday Times, Johannesburg, 28 April.

NYAMNJOH, FB, 2000. 'For many are called, but few are chosen': globalization and popular disenchantment in Africa. African Sociological Review, 4(2): 1-45.

ORGANIZATION OF AFRICAN UNITY (OAU), 1969. Convention governing the specific aspects of refugees in Africa. Article 2. Addis Ababa: OAU.

PADAYACHEE, N, 2002. Police bust R43 million Nigerian scam. Sunday Times, Johannesburg, 14 April.

PLANO, J \& ALTON, R, 1988. The international relations dictionary, 4th edition. Oxford: ABC-Clio, Inc.

RUSSETT, B \& STARR, H, 1988. World politics: the menu for choice, 2nd edition. New York: WH Freeman and Co.

SACHIKONYE, LM (Ed.), 1995. Labour migration in southern Africa. Harare: Southern Africa Printing and Publishing House (SAPPHO).

SADIE, Y, VAN AARDT, M \& VON BELOW, A, 1993. AIDS in Africa and its impact on the South African mining industry. Pretoria: Africa Institute of South Africa.

SCOBEY, D, 2001. The spectre of citizenship. Citizenship Studies, 5(1): 11-26.

SELINYANE, N, 2002. What has changed? One year of watching transformation. Public Eye (Maseru), 5-11 April.

SETSABI, S, 2003. The Third Wave. National University of Lesotho Information Flash, 9(1): 3-5, 10 January.

SICHONE, O, 2002. The making of 'makwerekwere': East Africans in Cape Town. Southern African Political and Economic Monthly, 14(8): 35-40.

SOUTHALL, R, 1984. Trade unions and the internal working class in Lesotho. South African Labour Bulletin, 10(3): 85-113.

STRANGE, S, 1991. An eclectic approach. In Murphy, CN \& Tooze, R (Eds), The new international political economy. Boulder: Lynne Rienner.

THE EMPLOYMENT BUREAU OF AFRICA (TEBA), 2001. Statistical Report. Maseru: TEBA.

TRANSFORMATION RESOURCE CENTRE (TRC), 1989. Health workers without jobs. Work for Justice, no. 10. Maseru: TRC. 
TRANSFORMATION RESOURCE CENTRE (TRC), 1996. Labour Migration and Related Issues. Work for Justice, no. 46. Maseru: TRC.

UNITED NATIONS (UN), 1948. Universal Declaration of Human Rights. New York: UN Department of Public Information.

UNITED NATIONS DEVELOPMENT PROGRAMME (UNDP), 2000. Human Development Report 2000. New York: Oxford University Press. 